pituitary source of ACTH and LPH concentrations of both peptides fell. The half time for the disappearance of ACTH was 40 minutes while, in contrast, B7-LPH and NZ-LPH had half lives of about 95 minutes. During hydrocortisone administration, therefore, there was an increasing dissociation between plasma ACTH and LPH.

\section{Discussion}

In normal subjects and in patients with excess ACTH-LPH production from a pituitary source ACTH plasma concentrations were equal to or higher than B7-LPH levels. The reversed relation between circulating plasma B7-LPH and ACTH concentrations in the ectopic ACTH-LPH syndrome might be due to differences in metabolic clearance rates between LPH and ACTH or even to circulating LPH precursors, which may be released because of abnormal hormone packaging within neoplastic tissue. ' Alternatively, the production of a large molecular weight ACTH precursor such as "big ACTH" might be responsible since it may not be fully immunoreactive and it is synthesised by some ectopic ACTH-secreting tumours. ${ }^{8}$

Since the NZ antiserum we used effectively measured only $\gamma-\mathrm{LPH}$, the concentrations of NZ-LPH found were lower than those of B7-LPH in patients with the ectopic ACTH-LPH syndrome. Lower $\gamma$-LPH than $\beta$-LPH may be characteristic of this condition, whereas a relatively higher proportion of $\gamma$-LPH seems to occur in the plasma of these patients with a pituitary source of ACTH and LPH. This may explain the findings of Shapiro et al, ${ }^{9}$ who showed, using chromatography, that ectopic
" $\beta-M S H$ " and pituitary " $\beta-M S H$ " were of different molecular weights. These differences between circulating LPH immunoreactivities, as well as their relation to ACTH concentrations, might be of value in deciding whether a patient with Cushing's syndrome has a pituitary or ectopic source of ACTH-a clinical problem which may present considerable diagnostic difficulty. The well-known dissociation between ACTH and " $\beta-M S H$ " in renal failure ${ }^{5}$ would not in practice be a problem, since plasma " $\beta-M S H$ " concentrations do not rise significantly until renal function is grossly impaired.

These studies were supported by a grant from the Cancer Research Campaign and the Joint Research Board of St Bartholomew's Hospital. We are grateful to Dr R A Donald for the gift of the NZ antiserum.

\section{References}

1 Abe, K, et al, fournal of Clinical Investigation, 1969, 48, 1580.

2 Scott, A P, and Lowry, P J, Biochemical fournal, 1974, 139, 593.

${ }^{3}$ Bloomfield, G A, et al, Nature, 1974, 252, 492.

${ }^{4}$ Gilkes, J J H, et al, fournal of Clinical Endocrinology and Metabolism, 1975, 40, 450.

${ }^{5}$ Gilkes, J J H, et al, British Medical fournal, 1975, 1, 656.

${ }^{6}$ Rees, L H, et al, Endocrinology, 1971, 89, 254.

${ }^{7}$ Rees, L H, Fournal of Endocrinology, 1975, 67, 143.

${ }^{8}$ Gewirtz, G, and Yalow, R S, fournal of Clinical Investigation, 1974, 53, 1022.

- Shapiro, M, et al, Fournal of Clinical Endocrinology and Metabolism, 1971, 33, 377 .

(Accepted 11 February 1977)

\title{
Inactivation of penicillin by purulent exudates
}

\author{
JOHN DE LOUVOIS, ROSALINDE HURLEY
}

British Medical fournal, 1977, 1, 998-1000

\begin{abstract}
Summary
Four of 22 specimens of human pus inactivated up to $90 \%$ of added penicillin within one hour in vitro. Ampicillin and cephaloridine were also inactivated, but streptomycin and fusidic acid were not. The effect was not related to the protein content of the pus, nor to its $\mathrm{pH}$ value. Microbes that may produce $\beta$-lactamase in small quantities were isolated from three of the four specimens, but the enzyme was not detected in the pus by physical methods nor by microbiological inhibition assay. The inactivating effect was shown to be a property of the solid portion of the pus, and was absent from the filtrate. We suggest that the effect may be an intrinsic property of the host, which should be investigated further as it has important implications for clinical practice.
\end{abstract}

\section{Introduction}

The tissues of some mammals contain enzymes capable of inactivating benzylpenicillin or its esters. Koch et al ${ }^{1}$ reported

\footnotetext{
Queen Charlotte's Maternity Hospital and the Institute of Obstetrics and Gynaecology, London W6 OXG

JOHN DE LOUVOIS, MSC, principal microbiologist

ROSALINDE HURLEY, MD, professor of microbiology
}

that rat brain contained a penicillinase that could destroy benzylpenicillin, and Snow ${ }^{2}$ showed an ester-specific $\beta$-lactamase in liver extracts from six species of mammals, excluding man, which converted the methyl ester of benzylpenicillin to the 3methyl ester of benzylpenicilloic acid. Esterase activity has been shown in the serum of rabbits, ${ }^{2}$ guinea pigs, mice, and rats. ${ }^{3} \mathrm{~A}$ $\beta$-lactamase-like enzyme has been found in the kidneys of albino mice. ${ }^{4}$ Neither $\beta$-lactamase nor any enzyme capable of hydrolysing simple penicillin esters has been shown in man. ${ }^{5}$

We report findings made in the course of establishing methods for assay of antibiotics in pus under conditions of transport $\left(4^{\circ} \mathrm{C}\right)$ or storage $\left(-20^{\circ} \mathrm{C}\right)$. The investigations were carried out on 22 samples of human pus, four of which were found to have a high level of activity against penicillin, ampicillin, and cephaloridine.

\section{Materials and methods}

Pus from 22 patients was examined. Sixteen patients had abscesses of the central nervous system and six had other purulent lesions. Measured quantities of antibiotics were added to pus, and assayed.

Test 1 -One $\mathrm{ml}$ saline containing $30 \mathrm{\mu g}$ penicillin was mixed with 4-ml aliquots of pus and of serum, the latter used as a control. After mixing at room temperature the samples were stored at $4^{\circ} \mathrm{C}$ for one hour, and after addition of equal parts of saline were assayed against penicillin standards in $50 \%$ horse serum using direct sensitivity test (DST) agar (Oxoid) at $\mathrm{pH} 7 \cdot 2$. The final concentration of penicillin in pus and in serum was thus $3.0 \mathrm{mg} / \mathrm{l}$.

Test 2-Penicillin, ampicillin, cephaloridine, streptomycin, and fusidic acid were each added to pus and to serum, so that the final concentrations before assay were $5.0,5.0,5.0,7.5$, and $1.0 \mathrm{mg} / \mathrm{l}$ respectively. The samples were divided; one set was assayed two 
hours after mixing, having been stored at $4 \mathrm{C}$; the other set was assayed 72 hours after mixing, having been stored at $-20^{\circ} \mathrm{C}$.

\section{ASSAY PROCEDURE}

Sixty $\mathrm{ml}$ of DST agar $\mathrm{pH} 7 \cdot 2$ cooled to $50^{\circ} \mathrm{C}$ was poured into a $15 \cdot 2-\mathrm{cm}$ diameter Petri dish (Sterilin) on a levelling table. When the medium had set the plate was dried at $37^{\circ} \mathrm{C}$ for $30-40$ minutes. A suspension of Staphylococcus aureus (NCTC 6571), consisting of a log-phase culture diluted to faint opacity and then further diluted $1 / 100$ in nutrient broth, was used to flood the plate. Excess broth was removed and the plate was again dried, before being kept at $4^{\circ} \mathrm{C}$. Before use, wells were cut with a No $2(6 \mathrm{~mm}$ diameter) or No 3 ( $8 \mathrm{~mm}$ diameter) sterile cork borer. The wells were filled at random with test and standard solutions in duplicate. The plate was allowed to prediffuse at $4{ }^{\circ} \mathrm{C}$ for one hour before being incubated at $37^{\circ} \mathrm{C}$ overnight. Zones of inhibition were read with calipers. The zone diameters of the standards were plotted against the log of their concentrations. The concentrations in the test fluids were determined from the line of best fit drawn through the standard points.

The specimens of pus were cultured and their protein content was determined by the salicylsulphonic acid method. ${ }^{6}$ The $\mathrm{pH}$ was determined by a unicam $290 \mathrm{pH}$ meter (Pye). Attempts were made to show $\beta$-lactamase activity by iodometry ${ }^{7}$ and by the electron-shift method of O'Callaghan et $a l^{8}$ as well as by microbiological assay of whole pus and of its fractions, as follows. Sensitivity medium (Oxoid DST) $\mathrm{pH} 7.2$ was flooded with a diluted broth suspension of Staph aureus (NCTC 6571) and dried. Wells $6 \mathrm{~mm}$ in diameter were cut $3 \mathrm{~cm}, 2 \mathrm{~cm}$, and $1 \mathrm{~cm}$ distant from a $2-\iota \mathrm{g}$ penicillin disc (Mast) and were filled with whole pus or with commercial $\beta$-lactamase solution in various dilutions. After prediffusion for 30 minutes at $4^{\circ} \mathrm{C}$, the plate was incubated overnight and the zone diameters of test and control were compared. Liquid samples of pus were centrifuged at $5000 \mathrm{rpm}$ for 30 minutes (BTL bench centrifuge, head radius $6.5 \mathrm{~cm}$ ), and the supernatant was passed through a 22-nm membrane filter. Centrifuged deposit, supernatant, and filtered supernatant were tested for neutralising effect on penicillin as before.

\section{Results}

Eighteen of 22 specimens yielded the expected concentration of penicillin that had been added to pus by the assay method used. Four yielded unexpectedly low concentrations, showing that $57-90 \%$ of added penicillin had been inactivated in one hour compared with controls (table I). There was insufficient pus to allow full investigation of the phenomenon for each of the four specimens. The effect on the activity of other antimicrobial drugs could only be tested in three specimens, and the effect of filtration could only be tested in two.

TABLE I-Effect of four specimens of pus on the activity of penicillin

\begin{tabular}{|c|c|c|c|c|c|c|c|}
\hline & & & & & & & Assay result (mg/l) \\
\hline $\begin{array}{l}\text { Serum control } \\
\text { Pus control } \ldots \\
\text { Pus sample } 1 \ldots \\
\text { Pus sample } 2 . \\
\text { Pus sample } 3 . \\
\text { Pus sample } 4 .\end{array}$ & $\begin{array}{l}\ldots \\
\cdots \\
\cdots \\
\cdots\end{array}$ & $\begin{array}{l}\cdots \\
\cdots \\
\cdots \\
\cdots\end{array}$ & $\begin{array}{l}\cdots \\
\because \\
\cdots \\
\cdots\end{array}$ & $\begin{array}{l}\because \\
\because \\
\cdots \\
\cdots\end{array}$ & $\begin{array}{l}\cdots \\
\because \\
\cdots \\
\cdots\end{array}$ & $\begin{array}{l}. \\
\because \\
\cdots \\
\cdots \\
\cdots\end{array}$ & $\begin{array}{l}3 \cdot 0 \\
3.0 \\
0 \cdot 3 \\
1.3 \\
0 \cdot 8 \\
0 \cdot 3\end{array}$ \\
\hline
\end{tabular}

Table II shows further the effect of three of these specimens on penicillin, and their effect on ampicillin, cephaloridine, streptomycin, and fusidic acid after storage of the mixtures for 2 and 72 hours at $4^{\circ} \mathrm{C}$ and $-20^{\circ} \mathrm{C}$ respectively before assay. Loss of activity is expressed as a percentage of that obtaining in control specimens of pus treated in the same way. Penicillin, ampicillin, and cephaloridine were inactivated, but streptomycin and fusidic acid were detected in the concentrations added. Inactivation was accomplished rapidly by specimens 1 and 2, altering little on further storage, while the effect was progressive with specimen 3 .

The sites of origin and the microbial flora of these four specimens were unremarkable compared with the other 18 specimens. Two derived from patients with abscesses of the central nervous system, one from an empyema, and one from a subphrenic abscess. They were free of detectable antimicrobial agents, as were the other specimens. Organisms of the Bacteroides group were isolated from two, Escherichia
TABLE II-Effect of three specimens of pus on the activity of antimicrobial drugs after storage for 2 and $72 \mathrm{~h}$ at $4^{\circ} \mathrm{C}$ and $-20^{\circ} \mathrm{C}$ respectively. Absence of result indicates no inactivation

\begin{tabular}{|c|c|c|c|c|c|}
\hline & \multirow{2}{*}{$\begin{array}{c}\text { Concentrations } \\
(\mathrm{mg} / \mathrm{l})\end{array}$} & \multirow{2}{*}{$\begin{array}{l}\text { Time (hours) } \\
\text { since mixing }\end{array}$} & \multicolumn{3}{|c|}{$\begin{array}{c}\text { Loss of activity (\%) } \\
\text { in samples }\end{array}$} \\
\hline & & & 1 & 2 & 3 \\
\hline Penicillin & $5 \cdot 0\{$ & $\begin{array}{r}2 \\
72\end{array}$ & $\begin{array}{l}>95 \\
>95\end{array}$ & $\begin{array}{l}74 \\
83\end{array}$ & $\begin{array}{l}58 \\
83\end{array}$ \\
\hline Ampicillin & $5 \cdot 0$ & $\begin{array}{r}2 \\
72\end{array}$ & $\begin{array}{r}90 \\
>95\end{array}$ & $\begin{array}{l}58 \\
58\end{array}$ & $\begin{array}{l}72 \\
86\end{array}$ \\
\hline Cephaloridine & $5 \cdot 0$ & 72 & $\begin{array}{r}88 \\
>95\end{array}$ & $\begin{array}{l}88 \\
88\end{array}$ & $\begin{array}{l}20 \\
56\end{array}$ \\
\hline Streptomycin & $7 \cdot 5$ & $\begin{array}{r}2 \\
72\end{array}$ & & & \\
\hline Fusidic acid & $1 \cdot 0$ & $\begin{array}{r}2 \\
72\end{array}$ & & & \\
\hline
\end{tabular}

coli from one, and the fourth had proved sterile, as originally reported. The $\mathrm{pH}$ values of the 22 samples were in the range $6 \cdot 0-7 \cdot 3$ and all had a protein content in the range $7-80 \mathrm{~g} / \mathrm{l}$. Those that inactivated penicillin contained no more protein than the others, nor were the concentrations higher than those of normal serum.

The physical methods for showing $\beta$-lactamase in neat pus proved unsuitable for technical reasons, but gave negative results when samples were diluted 1/10. Microbiological assay showed that commercial $\beta$-lactamase neutralised the antibacterial effect of penicillin on Staph aureus in an agar diffusion system, but no such effect was seen in any of the specimens of pus tested whole, showing that their activity against penicillin did not lie in a diffusible fraction. It seemed, therefore, that such activity must be intrinsic to the solid portion of the pus, and testing of centrifuged and filtered fractions indicated that this was so (table III). Specimen 1 was too viscous to be suitable for this experiment. It could not be separated satisfactorily by centrifugation, and would not pass a 22-nm membrane filter; activity against penicillin was demonstrable both in the deposit and in the unfiltered supernatant. After centrifugation, however, the clear supernatant from specimen 3 contained less than the added concentration of penicillin and there was some evidence of inactivation. There was no inactivation of penicillin in the fraction after removal of all particulate matter by filtration. Inactivation of cephaloridine was also shown to be a function of the solid portion of the pus.

TABLE III-Penicillin inactivation by two samples of pus containing $6 \mathrm{mg} / \mathrm{l}$ penicillin

\begin{tabular}{|c|c|c|c|}
\hline & $\begin{array}{l}\text { Mean zone size } \\
(\mathrm{mm})\end{array}$ & $\begin{array}{l}\text { Residual } \\
\text { penicillin } \\
\text { activity } \\
(\mathrm{mg} / \mathrm{l})\end{array}$ & $\begin{array}{c}\text { Inactivation } \\
(\%)\end{array}$ \\
\hline $\begin{array}{l}\text { Pus (sample 1) } \\
\text { Deposit } \\
\text { Unfiltered supernatant } \\
\text { Pus (sample 3) } \\
\text { Deposit } \\
\text { Unfiltered supernatant } \\
\text { Filtered supernatant }\end{array}$ & $\begin{array}{l}21 \cdot 8 \\
22 \cdot 0 \\
28 \cdot 3 \\
31 \cdot 2 \\
32 \cdot 0\end{array}$ & $\begin{array}{l}0.5 \\
0.5 \\
2.4 \\
5.0 \\
6.0\end{array}$ & $\begin{array}{r}>90 \\
>90 \\
60 \\
16\end{array}$ \\
\hline
\end{tabular}

\section{Discussion}

The experiments we have described were carried out on pus that had been stored at $4^{\circ} \mathrm{C}$ for two hours, or at $-20^{\circ} \mathrm{C}$ for three days as part of another investigation. Four of 22 samples of human pus tested inactivated up to $90 \%$ of added penicillin within one hour in vitro. The three that were further tested also inactivated ampicillin and cephaloridine. The specimens were not sufficiently large to allow adequate testing of their effects on cloxacillin and chloramphenicol, but there was no effect on streptomycin and fusidic acid. The observation that penicillin is inactivated by some specimens of pus might have important implications for clinical treatment. Were it to occur in vivo, it would account for some hitherto inexplicable failures of penicillin treatment. That it is likely to occur is suggested by our own failure to detect penicillins in specimens, including serum, when it seemed unreasonable to doubt that the drugs had been given. 
Penicillin is inactivated through being bound to protein and is destroyed by acid. The protein content of pus samples that inactivated penicillin did not differ substantially from that of other specimens, and $\mathrm{pH}$ for all was within the same range. Moreover, the detectable activity of acid-stable ampicillin was also diminished by specimens active against penicillin.

The possibility that the effect is due to the presence of $\beta$-lactamase-producing organisms cannot be discounted. $\beta$ Lactamase production has been described both for the Bacteroides group ${ }^{9}$ and for Esch coli. ${ }^{10}$ Unless the enzyme accumulated within the loculated pus it was unlikely to have produced such an effect, as enzyme production in these organisms is low. Penicillin may be inactivated within the bacterial cell since bacterial $\beta$-lactamase may not always be extracellular. ${ }^{11}$ The activity of pus did not lie in a diffusible fraction, and if it were ascribable to a bacterial enzyme we should have expected to find it in the extracellular fraction after the repeated freezing and thawing to which the specimens were subjected.

Penicillin inactivation may be a property of the host, as has been described for mammals other than man. Attempts to show activity against penicillin in tissue extracts and serum from healthy people have not succeeded, ${ }^{5}$ but so far as we are aware no studies have been made on the interaction of penicillins and host tissues in disease. Since both cephaloridine and benzylpenicillin are inactivated by specimens of human pus, the active principle is unlikely to be an esterase, and our results suggest that it is unlikely to be $\beta$-lactamase. If it is an enzyme it may be an amidase.

We are indebted to our clinical colleagues in a number of hospitals for providing the samples of pus used in this study.

\section{References}

1 Koch, E, et al, Archiv für Experimentelle Pathologie und Pharmakologie, 1953, 220, 157.

2 Snow, G A, Biochemical fournal, 1962, 82, 6.

${ }^{3}$ Ungar, J, British fournal of Experimental Pathology, 1947, 28, 88.

4 Shraer, D P, and Simonova, O D, Antibiotiki, 1970, 15, 254.

5 Richardson, A P, et al, Fournal of Pharmacology and Experimental Therapeutics, 1945, 85, 23.

${ }^{6}$ Kingsbury, J P, et al, fournal of Laboratory and Clinical Medicine, 1926, 11, 981 .

7 Sykes, R B, and Nordström, K, Antimicrobial Agents and Chemotherapy, $1972,1,94$

${ }^{8}$ O'Callaghan, C H, et al, Antimicrobial Agents and Chemotherapy, 1972, 1, 283.

- Anderson, J D, and Sykes, R B, fournal of Medical Microbiology, 1973, 6, 201.

${ }^{10}$ Percival, A, Brumfitt, W, and de Louvois, J, fournal of General Microbiology, 1963, 32, 77 .

11 Sykes, R B, and Matthew, M, Fournal of Antimicrobial Chemotherapy, 1976, 2, 115.

(Accepted 4 March 1977)

\title{
Suspension of non-viable fungal spores as a standard for platelet counting
}

\author{
R K ARCHER， MARYTAVY ARCHER， B V ALLEN
}

British Medical fournal, 1977, 1, 1000-1001

\begin{abstract}
Summary
In the search among biological particles for a standard for counting human platelets, a strain of Absidia corymbifera was found to have spores that resembled platelets. After fixing in formalin and autoclaving the spores had a similar mean cell volume to that of human platelets. A suspension of these killed spores was tested in $\mathbf{1 0 0}$ laboratories and gave consistent results as a standard for human platelet counting. The Absidia corymbifera standard can be used in electronic counting methods but not in sedimentation methods, as the spores will be removed by centrifugation.
\end{abstract}

\section{Introduction}

The production of a satisfactory standard for counting platelets, whether by manual methods or by electronic instruments, has proved difficult. Fresh platelets are viable for only a few hours,

\footnotetext{
Equine Research Station, Animal Health Trust, Balaton Lodge, Newmarket, Suffolk CB8 7DW

R K ARCHER, SCD, FRCVs, haematologist

MARYTAVY ARCHER, BSC, DIC, mycologist

B V ALLEN, FIMLS, haematologist
}

and when fixed-for example, in glutaraldehyde-they tend to shrink and form clumps, thus becoming too small to serve as a standard besides being most difficult to resuspend.

One possible approach has been to find naturally occurring biological particles that might serve as a standard for human blood platelets. Various erythrocytes of different species have been investigated, but none has a sufficiently small mean cell volume. A prolonged search among the spores of fungi and moulds has shown that the fungus Absidia corymbifera, which is commonly found in soil, produces spores that look similar to platelets. Furthermore, after fixation in formalin followed by autoclaving an isolate of this fungus was found with spores that have a similar mean cell volume to that of human platelets. Spores so treated, unlike fixed platelets, do not tend to form clumps and they have a distribution by cell size comparable to that of normal human platelets.

\section{Methods}

The particular strain of Absidia corymbifera used ((Cohn) Sacc and Trott) is identified as No ERS 467. Cultures of the fungus are maintained within the laboratory according to the Commonwealth Mycological Institute procedure for storing cultures on silica gel. ${ }^{1}$ In this state cultures remain viable for many years.

When a batch of spores is to be prepared a few grains of the silica gel bearing the culture are placed in a Petri dish containing potato dextrose agar (PDA) (Oxoid). Incuabtion at $25^{\circ} \mathrm{C}$ gives a good growth at five to 10 days.

From this Petri dish several slopes of PDA in universal bottles are inoculated and incubated for seven to 14 days. At this stage the slopes can be stored at $+4^{\circ} \mathrm{C}$ for several weeks. When required the slopes are filled with sterile water, shaken up, and about $2-\mathrm{ml}$ portions used 